Pace University

DigitalCommons@Pace

$5-11-2007$

\title{
Integrating the Complexity of Mental Disability into the Criminal Law Course
}

Linda C. Fentiman

Elisabeth Haub School of Law at Pace University

Follow this and additional works at: https://digitalcommons.pace.edu/lawfaculty

Part of the Criminal Law Commons, Health Law and Policy Commons, Legal Education Commons, and the Medical Jurisprudence Commons

\section{Recommended Citation}

Linda C. Fentiman, Integrating the Complexity of Mental Disability into the Criminal Law Course" (2007). Pace Law Faculty Publications. Paper 341. http://digitalcommons. pace.edu/lawfaculty/341.

This Article is brought to you for free and open access by the School of Law at DigitalCommons@Pace. It has been accepted for inclusion in Pace Law Faculty Publications by an authorized administrator of DigitalCommons@Pace. For more information, please contact dheller2@law.pace.edu. 


\title{
INTEGRATING THE COMPLEXITY OF MENTAL DISABILITY INTO THE CRIMINAL LAW COURSE $\stackrel{-}{-}$
}

\author{
by \\ Linda C. Fentiman
}

\section{INTRODUCTION}

Teaching criminal law is one of the great passions of my life. In the twenty years that I have being doing this, I have found that integrating mental disability law themes into the course materials and class discussions makes criminal law a much richer class. Including mental disability law issues achieves four important goals. The first goal is to make explicit the tensions that inhere in a modern criminal justice system, which, in seeking to hold people accountable for their actions assumes that behavior is "chosen," at the same time that an expanding body of scientific evidence demonstrates that much, if not all, human behavior, is shaped profoundly by environmental and genetic factors. The normative question of when a biological/psychological/environmental "explanation" for behavior ought to mitigate or excuse a person's criminal responsibility permeates the criminal law course, arising in such diverse arenas as the purposes of punishment, actus reus and mens rea, homicide, causation, and affirmative defenses, including self-defense, insanity, and duress. The second goal is to increase students' awareness of, and comfort

\footnotetext{
๑ 2007 Linda C. Fentiman

- Professor, Pace University School of Law; B.S. Cornell University, J.D. S.U.N.Y. Buffalo Law School, LL.M. Harvard University. I am grateful for the insights of colleagues who commented on the draft,
} 
with, the language of neuroscience, psychiatry, and psychology, so that they can better understand and evaluate judicial opinions and other public pronouncements. The third goal is to help students understand the significant connections between mental disability issues and gender discrimination. Last, and not always least, I teach about mental disability in the criminal law course in order to recruit students for my upper level seminar on mental disability law.

Mental disability ${ }^{1}$ issues can be discussed on a multitude of occasions in the course on criminal law. My own idiosyncratic approach emphasizes mental disability's intersections with the doctrinal aspects of criminal law. ${ }^{2}$ These intersections fall into five categories: 1) the justifications for punishment; 2) the definition of crime in general, to wit, the requirements of a voluntary act, mens rea, and causation; 3) the definition of particular crimes, such as murder, manslaughter, rape, and burglary; 4) defenses to crime, including mistake of law and of fact, as well as justification (including self-defense) and excuse (including insanity and duress); and 5) considerations in sentencing, including

including Debby Denno, Josh Dressler, Jill Gross, Tim Hall, John LaFond, Michael Perlin, Audrey Rogers, Bob Schopp, and Chris Slobogin.

${ }^{1}$ In this article, I will generally use the term "mental disability" to include both mental illness, which encompasses the increasingly broad range of mental disorders recognized by the American Psychiatric Association in its Diagnostic and Statistical Manual (see DSM IV-R ( ), and mental retardation. In particular sections of this article, I will focus more specifically on mental illness or mental retardation.

${ }^{2}$ Another interesting approach, taken by Villanova Law Professor Richard Redding, focuses on exposing students to the practical, procedural aspects of having a criminal client with a mental disability. Richard E. Redding, Why It is Essential to Teach About Mental Health Issues in Criminal Law (And a Primer on How To Do It), 14 Wash U. J. Law \& Pol. 407 (2004). 
the death penalty and sex offenses. The examples I use are drawn from a variety of criminal law case books. ${ }^{3}$

\section{Bases for Punishment}

At the outset of most criminal law courses, students will consider the purposes of punishment: retribution, deterrence, incapacitation, and rehabilitation. This is a good time to ask students to consider the relevance of mental disability in deciding how the purposes of punishment may be achieved, both in general and in particular cases. For example, a discussion of retribution should include materials which permit students to understand that mental illness or mental retardation can render persons less culpable for their behavior, even as their conduct prompts outrage or horror. In discussing deterrence, students should be asked to consider whether a defendant's mental disability makes it more or less likely that he can be specifically deterred from future criminality and whether others will be deterred if he is punished. ${ }^{4}$ Although the rehabilitative model has largely been rejected by this country's legislatures, students can be exposed to the idea that rehabilitation, including mental health treatment, may render some people less dangerous and therefore less in need of incapacitation through physical confinement. Discussions of punishment also provide an excellent opportunity to expose students to

\footnotetext{
${ }^{3}$ These include Joshua Dressler, Richard J. Bonnie, Markus Dubler, Sanford H. Kadish and Stephen J. Schulhofer, CRIMINAL LAW AND ITS PROCESSES: CASES AND MATERIALS (7th ed. 2001), Kaplan and Weisberg, and Perkins and Boyce.

${ }^{4}$ This is also an appropriate occasion for discussing whether a defendant's substance abuse should affect his culpability. See also discussion of Robinson v. California, 370 U.S. 660 (1962) and Powell v. Texas, 392 U.S. 514 (1968), infra in text accompanying n’s [ 10-11].
} 
rudimentary concepts of mental disability, for example, the differences between mental illness (including psychosis, neurosis, mood disorders, and personality disorders) and mental retardation, and to help understand and critique the role of psychiatrists, psychologists, and neuroscientists as expert witnesses in criminal trials.

\section{The Requirements of a Crime - Act, Mens Rea, and Causation}

Discussing the general requirements of criminal culpability also provides the occasion for discussing mental disability. When we address the essential requirements of a voluntary act, mens rea, and causation, mental disability figures prominently. In the classic case of People v Newton, ${ }^{5}$ Huey Newton's conviction for manslaughter was reversed for failure to instruct the jury that unconsciousness is a complete defense under California law. ${ }^{6}$ In the Kadish and Schulhofer casebook, the Newton case is followed by notes on other "involuntary act" cases, including the epileptic driver in People v. Decina, ${ }^{7}$ and the sleepwalking Mrs. Cogdon, discussed by Norval Morris. ${ }^{8}$ These cases can and should be updated by Professor Deborah Denno's recent article on Crime and Consciousness. ${ }^{9}$

\footnotetext{
${ }^{5}$ People v. Newton, 87 Cal. Rptr. 394 (Cal. Ct. App. 1970). In reversing the conviction, the California Supreme Court noted that the jury had been instructed on diminished capacity as a mitigating factor, and observed that " $[\mathrm{t}] \mathrm{he}$ difference between the two states - of diminished capacity and unconsciousness - is one of degree only," as the former provides a "'partial defense'” by negating the relevant mens rea, while the latter "negates capacity to commit any crime at all." Id. at 405-06. Thus, the Newton case also provides the opportunity to discuss the continuum of mental states and mental state defenses.

${ }^{6}$ At the time, Cal. Pen. Code $\S 26$ provided that, "All persons are capable of committing crimes except those belonging to the following classes: ... Five--Persons who committed the act charged without being conscious thereof.” This rule continues today in a renumbered Section Four.

${ }^{7} 238$ N.E.2d 799 (N.Y. 1956).

${ }^{8}$ Norval Morris, Somnambulistic Homicide: Ghosts, Spiders, and North Koreans, 5 Res Judicatae 29 (1951).

${ }_{9}^{9}$ Deborah Denno, Crime and Consciousness, Science and Involuntary Acts, 87 Minn. L. Rev. 269 (2002).
} 
Denno argues that the classic dichotomy between conscious and unconscious, and voluntary and involuntary acts needs to be revised in light of modern neuroscience research, in order to achieve more consistent, and therefore more just, results for individuals relying on the defenses of insanity or unconsciousness.

The emphasis on volitional behavior in Anglo-American criminal law could also be explored at this juncture by discussing drug and alcohol addiction, and students should be made aware of the large number of criminal defendants who suffer both from mental illness and substance abuse. Using the cases of Robinson v. California ${ }^{10}$ and Powell v. Texas, ${ }^{11}$ students can understand the difficulties in neatly conceptualizing behavior as either volitional, and therefore blameworthy, or involuntary, and therefore noncriminal. While drawing these fuzzy lines may be inconvenient at this early point in the semester, when we seek to help students develop some clear organizing principles for criminal law, addressing these cases now has the advantage of putting students on notice that there are few black and white principles in the criminal law. Furthermore, introducing students to the expert testimony of neuroscientists, psychiatrists, and psychologists will make them more attuned to the significant role such experts play in framing and answering questions about criminal responsibility and more alert to the pitfalls of reliance on this expertise. Discussion of cases like and also show students how significant expert testimony can be, and how difficult, yet important it is,

${ }^{10} 370$ U.S. 660 (1962). 
to separate clinical/scientific expertise from the legal question that the expert is being asked to address. ${ }^{12}$

The subject of causation in criminal law also provides an excellent opportunity to talk about mental disability issues. Here, one can confront directly the arbitrariness of the criminal law in deciding when subsequent human action cuts off a causal chain set in motion by the defendant, and when it does not. Comparing the cases of People $v$. Campbell ${ }^{13}$ and Stephenson v. State ${ }^{14}$ can be very useful. In Campbell, the defendant was angry with a man who had sex with his wife, and encouraged him to kill himself, going so far as to provide him with the weapon. The victim obliged, and Campbell was charged with murder. On appeal, the Michigan Court of Appeals quashed the prosecution, because the court found that the victim's independent actions had caused

11392 U.S. 514 (1968).

${ }^{12}$ This issue is raised, inter alia, in the insanity defense and self-defense contexts, but it is not too early in the course to consider efforts to reign in the role of experts, such as Congress's enactment of the Insanity Defense Reform Act in response to John Hinckley's acquittal on grounds of insanity. In this Act, Congress amended the federal insanity defense to declare that:

....It is an affirmative defense to a prosecution under any Federal statute that, at the time of the commission of the acts constituting the offense, the defendant, as a result of a severe mental disease or defect, was unable to appreciate the nature and quality or the wrongfulness of his acts. Mental disease or defect does not otherwise constitute a defense.

18 U.S.C. $\$ 17$ (a).

At the same time, Congress amended Rule 704 of the Federal Rules of Evidence to provide that: Opinion on Ultimate Issue.

(a) Except as provided in subdivision (b), testimony in the form of an opinion or inference otherwise admissible is not objectionable because it embraces an ultimate issue to be decided by the trier of fact.

(b) No expert witness testifying with respect to the mental state or condition of a defendant in a criminal case may state an opinion or inference as to whether the defendant did or did not have the mental state or condition constituting an element of the crime charged or of a defense thereto.

Such ultimate issues are matters for the trier of fact alone.

As the Court of Appeals for the Seventh Circuit noted in United States v. West, 962 F.2d 1243 (7th Cir. 1992), Congressional action in the Insanity Defense Reform Act reflects its "skepticism not about the spectacle of competing mental health experts and their conflicting testimony but about their competence to testify about moral questions of criminal responsibility.” Id. at 1248.

${ }^{13} 335$ N.W.2d 27 (Mich. App. 1983). 
his death. In contrast, in Stephenson the defendant, who was the head of the Indiana Ku Klux Klan, was convicted of murder when the victim of his kidnapping and rape swallowed poison in an effort to escape both him and the public shame of having been attacked and degraded by him. In affirming the conviction, the Indiana Supreme Court declared that to fail to find causation "would be a travesty on justice." 15 While one can view the Court's decision as warranted by the defendant's brutality and dangerousness, as law teachers we should be concerned with the extreme stretch the court made in order to justify affirmance of the conviction, as it was necessary to find the victim absolutely mentally irresponsible in order to conclude that her act of taking poison did not sever the causal chain set in motion by the defendant. The Stephenson case thus offers a good opportunity for students to comment on the Court's gendered response to alleged incapacity and vulnerability. Stephen Miles and Allison August have discussed the gendered nature of judicial analysis of incompetent individuals' previously expressed preferences about foregoing life-sustaining medical treatment, finding that courts tend to ignore or disparage statements made by competent women about their wish to die if particular circumstances arise, frequently dismissing the women's previous statements as "unreflective and emotional."16 So too, by contrasting the Campbell and Stephenson cases, we can explore gender stereotypes about mental illness and voluntary and involuntary human action. Planting the seeds of this discussion now can bear fruit later in the criminal law course, when one discusses rape and rape shield

\footnotetext{
${ }^{14} 179$ N.E. 633 (Ind. 1932).

${ }^{15}$ Id. at 649.
} 
laws, the battered women's syndrome in the context of self-defense and duress, and the gendered aspects of capital sentencing.

\section{SPECIFIC CRIMES}

\section{A. Homicide}

Much of criminal law, and particularly the law of homicide, focuses on identifying the mens rea required to commit a specific crime, and the policy implications of that choice. One area in which mental disability issues are easily taught is in comparing the common law defense of provocation/heat of passion ${ }^{17}$ with the more modern Model Penal Code defense of extreme emotional disturbance. ${ }^{18}$ This defense permits mental illness and other psychological abnormalities not rising to the level of insanity to mitigate murder to manslaughter, when the traditional heat of passion defense would not. At the same time, as the Casassa ${ }^{19}$ case indicates, even the more generous extreme emotional disturbance defense provided under the Model Penal Code and the

\footnotetext{
${ }^{16}$ Stephen Miles \& Allison August, Courts, Gender and "The Right to Die," 18 Law Med. \& Health Care 85, 88 (1990).

${ }^{17}$ For a classic statement of this doctrine, see, e.g., Maher v. People, 10 Mich. 212, 81 Am. Dec. 781 (Mich. 1862).

${ }^{18}$ Model Penal Code $\S 210.3$ provides that a criminal homicide "which would otherwise be murder" is mitigated to manslaughter when "(b) ... [it] is committed under the influence of extreme mental or emotional disturbance for which there is reasonable explanation or excuse. The reasonableness of such explanation or excuse shall be determined from the viewpoint of a person in the actor's situation under the circumstances as he believes them to be."

${ }^{19}$ People v. Casassa, 404 N.E. 2d 1310 (N.Y. 1980).
} 
New York Penal Code ${ }^{20}$ has its limits, and not all mental disability will be seen as mitigating criminal responsibility.

Indeed, how far to subjectivize the reasonable person is a perennial dilemma in the criminal law. The difficulties in establishing the parameters of the reasonable person are illustrated by the poorly educated Native American parents in the Williams ${ }^{21}$ case, who were convicted of manslaughter based on child neglect, the adolescent defendant aggrieved by being sodomized and then laughed at in Camplin, ${ }^{22}$ and the squishy notions of the reasonable person in self-defense, be it battered women or the "reasonable racist" 23 in the Goet $z^{24}$ case. By explicitly discussing mentally disabled defendants and the questions of how to define mental disability and how to operationalize the reasonable mentally ill or mentally retarded defendant students will better understand the problem of the reasonable person in the criminal law.

\section{B. Rape}

\footnotetext{
${ }^{20}$ N. Y. Penal Code $\S 125.25$ tracks the language of the Model Penal Code closely. In pertinent part, it provides that:

A person is guilty of murder in the second degree when:

1. With intent to cause the death of another person, he causes the death of such person or of a third person; except that in any prosecution under this subdivision, it is an affirmative defense that:

(a) The defendant acted under the influence of extreme emotional disturbance for which there was a reasonable explanation or excuse, the reasonableness of which is to be determined from the viewpoint of a person in the defendant's situation under the circumstances as the defendant believed them to be. Nothing contained in this paragraph shall constitute a defense to a prosecution for, or preclude a conviction of, manslaughter in the first degree or any other crime....

${ }^{21}$ State v. Williams, 484 P.2d 1167 (Wash. Ct. App. 1971).

${ }^{22}$ D.P.P. v. Camplin, [1978] A.C. 705 (2 All E.R. 168).

${ }^{23}$ See Jody D. Armour, Race Ipsa Loquitur: Of Reasonable Racists, Intelligent Beyesians, and Involuntary Negrophobes, 46 Stanford L. Rev. 781 (1994), cited in Sanford H. Kadish and Stephen J. Schulhofer, CRIMINAL LAW AND ITS PROCESSES: CASES AND MATERIALS, supra n. [2] at 757-59.
} 
The crime of rape permits the discussion of several important mental disability issues. First, the question of how mental disability can affect consent should be examined from the perspective of both a mentally disabled defendant ${ }^{25}$ and a mentally disabled victim. ${ }^{26}$ The limits on aggressive cross-examination of the prosecutrix, including the desirability and constitutionality of rape shield laws and the extent to which the victim's mental health may be explored by defense counsel, have long been controversial. ${ }^{27}$ There is ongoing debate about whether motions to compel the release of the victim's psychotherapy records or even to compel her to submit to a psychiatric evaluation prior to trial are a necessary aspect of the Sixth Amendment right to confrontation $^{28}$ or, instead, serve as examples of the gender bias of an inequitable criminal justice system, which places the victim on trial and forces her to suffer further humiliation and mental anguish. ${ }^{29}$ An open exploration of the connection between gender bias and our socially constructed notions of mental illness will bear fruit throughout the criminal law course.

\footnotetext{
${ }^{24}$ People v. Goetz, 497 N.E. 2d 41 (N.Y. 1986).

25

${ }^{26}$ See generally Wayne R. LaFave, CRIMINAL LAW 872-73 (4th ed. 2003).

${ }^{27}$ See generally Wayne R. LaFave, CRIMINAL LAW 882-83 (4th ed. 2003).

${ }^{28}$ See, e.g., Pennsylvania v. Ritchie, 480 U.S. 39 (1987) (holding in the case of a father charged, inter alia, with rape and incest, that the defendant's Sixth Amendment right to confrontation and compulsory process were not violated by a failure to disclose his daughter's statements to a state child protective agency), Commonwealth v. Kyle, 533 A.2d 120 (Pa. Super. 1987) (holding that a defendant charged with rape and sexual assault was not entitled to see the victim's post-crime psychological counseling records), Commonwealth v. Sciuto, 623 F.2d 869 (3rd Cir. 1980) (upholding the trial court's refusal to order a psychiatric examination of the prosecutrix as within the court's discretion).

${ }^{29}$ See generally Wayne R. LaFave, CRIMINAL LAW 882-83 (4th ed. 2003), Susan Estrich, Palm Beach Stories, 11 Law \& Phil. 5, 17-18 (1992), cited in Kadish \& Schulhofer, supra n. [2], at 385-86.
} 


\section{DEFENSES TO CRIME}

\section{A. Mistake Of Law}

Mental disability issues often arise in the context of a "cultural defense" case, when a defendant claims that her actions, while not legal in the United States, would be lawful under the law of her home country or culture. In the Kimura ${ }^{30}$ case, a JapaneseAmerican woman drowned her two children in an attempt to commit oyakoshinju, or parent-child suicide, after learning of her husband's extramarital affair. "'In traditional Japanese culture, the death ritual was an accepted means for a woman to rid herself of the shame resulting from her husband's infidelity.'"31 In this case, the defendant sought initially to assert a defense of mistake of law or a cultural defense, but the district attorney found this unacceptable. Instead, the defendant entered a plea bargain in which she agreed to accept psychiatric treatment and one year in jail. Thus, to reach what was seen as a just result without opening the Pandora's box of cultural defenses, mental disability, perhaps manufactured, was used as mitigation, if not excuse.

\section{B. Mistake of Fact}

Defendants' mental disabilities are often relevant in determining whether they have a mistake of fact defense. As noted above, in rape cases, a defendant's mental

\footnotetext{
${ }^{30}$ People v. Kimura, cited by Michelle Oberman, Criminal Law: Understanding Infanticide in Context: Mothers Who Kill, 1870-1930 and Today, 92 J. Crim. L. \& Criminology 707 (2002).
} 
disability can bear on the question of whether he mistakenly believed the victim was consenting to intercourse. ${ }^{32}$ In the context of burglary, a defendant's mental illness has also been deemed relevant to whether he was acting under a mistake of fact which precluded his possessing the mental state necessary to commit burglary. In People $v$. Wetmore $^{33}$ the defendant had long history of hospitalization for mental illness. On release from a Veterans Administration hospital, he entered an unlocked, temporarily unoccupied apartment and made himself at home, wearing the owner's clothes and cooking his food, under the delusion that this was his own apartment. The trial court refused to permit the defendant to offer psychiatric testimony about his mental disability to show that he lacked the specific intent required for burglary - the intent to commit a felony in the dwelling of another. ${ }^{34}$ The California Supreme Court reversed, holding that such mental state evidence must be admitted whenever it is relevant on the question of mens rea. ${ }^{35}$ The Wetmore case would prove useful on a multiple levels - in teaching the elements of burglary, as well as exposing students to the breadth and complexity of mental disabilities that exist, and the fact that they range along a continuum, with multiple shades of gray, rather than existing as black/white, on/off phenomena.

\section{THE INSANITY DEFENSE}

\footnotetext{
${ }^{31}$ Id. at 733, n. 112, citing Note, The Cultural Defense in the Criminal Law, 99 Harv. L. Rev. 1293, 129394 (1986).

33149 Cal. Rptr. 265, 583 P.2d 1308 (Cal. 1978).

${ }^{34}$ Under California Penal Code $\S 459$, “Every person who enters any house, room, apartment ... with intent to commit grand or petit larceny or any felony is guilty of burglary. ...”
} 
Many criminal law professors shy away from teaching insanity, often claiming the press of time. However, I suspect that this choice often reflects a professor's own lack of comfort with the subject matter. In contrast, since I love the insanity defense, I always teach it. I have found that focusing on the details of the ALI-Model Penal Code, $^{36} \mathrm{M}^{\prime}$ Naghten, $^{37}$ and Durham ${ }^{38}$ tests is less successful than using one case to illustrate many of the strengths and weaknesses of the insanity defense. In recent years, I have used with considerable success the case of Charles Heads, presented in the Reisner, Slobogin, and Rai book, Law and the Mental Health System: Civil and Criminal Aspects. ${ }^{39}$ The Heads case involved a Vietnam vet experiencing post-traumatic-stress disorder who killed his brother-in-law, ostensibly while he experienced a "flashback" in which he believed that he was in Vietnam, under attack. ${ }^{40}$ This case permits students to

${ }^{35} 149$ Cal. Rptr. at 269, 583 P.2d at 1312.

${ }^{36}$ The American Law Institute’s Model Penal Code $\S 4.01$ provides:

(1) A person is not responsible for criminal conduct if at the time of such conduct as a result of mental disease or defect he lacks substantial capacity either to appreciate the criminality [wrongfulness] of his conduct or to conform his conduct to the requirements of law.

(2) As used in this Article, the terms "mental disease or defect" do not include an abnormality manifested only by repeated criminal or otherwise anti-social conduct.

${ }^{37}$ The rule in M'Naghten's Case was announced after an outpouring of public opinion against a jury's finding that Daniel M'Naghten was not guilty by reason of insanity for murdering Edmund Drummond, the secretary to Prime Minister Robert Peel, whom M'Naghten mistook for Peel. Responding to a parliamentary inquiry, the English judges told the House of Lords that:

To establish a defense on the ground of insanity, it must be clearly proved that, at the time of the committing of the act, the party accused was laboring under such a defect of reason, from disease of the mind, as not to know the nature and quality of the act he was doing; or, if he did know it, that he did not know he was doing what was wrong.

10 Cl. \& F 200, 8 Eng. Rep 718 (1843).

${ }^{38}$ The Durham test, which governed in the D.C. Circuit from 1954 to 1972, provided that "an accused is not criminally responsible if his unlawful act was the product of mental disease or defect." Durham v. United States, 214 F.2d 862 (D.C. Cir. 1954).

${ }^{39}$ Ralph Reisner, Christopher Slobogin, and Arti Rai, LAW AND THE MENTAL HEALTH SYSTEM: CIVIL AND CRIMINAL ASPECTS (4th ed. 2004).

${ }^{40} I d$. at $540-45$. 
understand the various doctrinal approaches to the insanity defense, particularly the difference between the cognitive and volitional prongs of the insanity standard. It also helps students appreciate the importance of psychiatric expert witnesses, and the significance of whether a particular psychiatric or psychological condition is recognized by the Diagnostic and Statistical Manual ${ }^{41}$ in determining an insanity defense's success.

In addition, almost every year there is a celebrated media case - a few years ago, it involved Andrea Yates ${ }^{42}$ - that helps dramatize the issues of insanity. Over and over, I have been struck by how resistant students are to the idea of the insanity defense, illustrating what Michael Perlin calls "sanism." 43 Teaching the insanity defense using current as well as older cases exposes students to important issues about mental disability and criminal responsibility and can help them confront their own prejudices and preconceptions, including gender biases about what constitutes "craziness."

In addition, it is possible to develop research and writing problems using the insanity defense. At Pace Law School, where criminal law is taught as a two-semester course combining legal research and writing with substantive criminal law, I was able to give students more in-depth exposure to the insanity defense by devising a problem which raised the issue of whether the insanity defense should be available in juvenile

\footnotetext{
${ }^{41}$ American Psychiatric Association, Diagnostic and Statistical Manual IV-TR ( ).

${ }^{42}$ Yates v. State, 2005 Tex. App. LEXIS 81 (Tex. Ct. App. June 6, 2005) (reversing the murder conviction of a mother of five children who drowned them, believing because of psychotic delusions that they would be better off dead than "perish[ing] in the fires of hell").

${ }^{43}$ Michael Perlin, "You Have Discussed Lepers and Crooks": Sanism in Clinical Teaching, 9 Clinical L. Rev. 683 (2003).
} 
court. ${ }^{44}$ Using this problem permitted me to educate students about the juvenile court system, and to explore the similarities and differences between incapacity due to age and due to mental illness or mental retardation.

\section{DURESS}

Duress provides an excuse to crime when the criminal act was performed in response to an imminent threat of serious bodily harm or death to the defendant or another, under circumstances in "which a person of reasonable firmness...would have been unable to resist." ${ }^{45}$ The note cases in Kadish \& Schulhofer ${ }^{46}$ are very useful in pushing students to confront the outer limits of duress, and permits a consideration of difficult issues related to mental disability. The cases ask whether mental retardation, multiple personality disorder, and battered women's syndrome are relevant, and therefore admissible, on the question of duress. Discussion of these cases helps students explore the fundamental purposes of providing an excuse for duress and also helps them confront latent gender bias in the law.

\footnotetext{
${ }^{44}$ State courts are divided on this issue. See, e.g., In re Winburn, 145 N.W.2d 178, 184 (holding that due process requires that an insanity defense be permitted in juvenile delinquency proceedings) and People v. Golden, 21 S.W.3d 801, 803-04 (Ark. 2000) (holding that neither due process nor equal protection principles require states to provide an insanity defense for juveniles, even if such a defense is authorized for adult criminal defendants).

${ }^{45}$ See, e.g., Model Penal Code $\S 2.09$ (1).

${ }^{46}$ Sanford H. Kadish and Stephen J. Schulhofer, CRIMINAL LAW AND ITS PROCESSES, supra n. [2], at 851-52. These notes raise the question of how much the reasonable person should be subjectivized, and include Zelenak v. Commonwealth, 475 S.E.2d 853 (Va. App. 1996); Regina v. Bowen, [1996] Crim L. Rev. 577, 578; United States v. Willis, 38 F.3d 170 (5th Cir. 1994); and United States v. Marenghi, 893 F. Supp. 85 (D. Me. 1995).
} 


\section{E. SELF-DEFENSE}

Discussion of battered women's syndrome and other mental illnesses clarify some of the difficulties with self-defense. The classic requirements of self-defense are that there be an immediate threat of deadly force, a reasonable belief in the necessity of deadly force, and the lack of a duty to retreat. ${ }^{47}$ When we consider the meaning of these requirements, we explore the cultural and gendered underpinnings of self-defense law, and confront again the difficulty of subjectivizing the reasonable person, whether it is the reasonable battered woman, the reasonable racist, 48 or the reasonable battered child. ${ }^{49}$ At the same time, Robert Schopp, Barbara Sturgis, Megan Sullivan, ${ }^{50}$ and Susan Estrich $^{51}$ have made clear the problems of developing a defense predicated on a genderspecific mental disability, as opposed to taking into account some of the unique characteristics of every defendant in evaluating the reasonableness of her use of deadly force in response to threats by a victim.

\footnotetext{
${ }^{47}$ United States v. Peterson, 483 F.2d 1222 (D.C. Cir. 1973), State v. Abbott, 174 A.2d 881 (N.J. 1961).

48 People v. Goetz, 497 N.E.2d 41 (N.Y. 1986), Jody D. Armour, Race Ipsa Loquitur: Of Reasonable Racists, Intelligent Beyesians, and Involuntary Negrophobes, supra n. [20].

49 Jahnke v. State, 682 P.2d 991 (Wyo.1984).

${ }^{50}$ Robert Schopp, Barbara Sturgis, Megan Sullivan, Battered Women's Syndrome, Expert Testimony, and the Distinction Between Justification and Excuse, 1994 U. Ill. L. Rev. 45 (1994).
} 


\section{SENTENCING CONSIDERATIONS}

\section{A. The Death Penalty}

The role of mental disability in sentencing brings us full circle in criminal law, as we reexamine the justifications for punishment. This happens with special poignancy in the death penalty context, when we consider whether a defendant's mental disability constitutes a mitigating circumstance and also when we examine cases in which mental disability is cited as an aggravating factor. In both types of cases, students are forced to confront their own stereotypes about the extent to which mentally ill or mentally retarded individuals are less competent and less morally responsible, as well as more likely to be violent, than the average person. ${ }^{52}$ Finally, consideration of mental disability in capital sentencing dovetails in important ways with a discussion of racial and gender disparities in jury assessments of death penalty appropriateness. ${ }^{53}$

\footnotetext{
${ }^{51}$ Susan Estrich, Defending Women (Book Review, Cynthia Gillespie, Justifiable Homicide: Battered Women, Self-Defense, and the Law (1989), 88 Mich. L. Rev. 1430, 1434-37 (1990), excerpted in Kadish \& Schulhofer, supra n. [2], at 772-73.

${ }^{52}$ See generally the discussion in Reisner, Slobogin, and Rai, supra n. [34], at 463-68 and 470-74, summarizing the literature.

${ }^{53}$ See, e.g., McCleskey v. Kemp, 481 U.S. 279 (1987) (holding that statistical disparities in the rates at which the death penalty was imposed in Georgia on white and black defendants convicted of murder and of those murderers convicted of killing black v. white victims was not in itself grounds for invalidating the death sentence imposed in this case, absent a showing that the jury acted on the basis of race here), $c f$. James Liebman, Jeffrey Fagan \& Valerie West, A BROKEN SYSTEM: ERROR RATES IN CAPITAL CASES, 1973-1995 (2000); Craig Haney, Condemning The Other In Death Penalty Trials: Biographical Racism, Structural Mitigation, And The Empathic Divide, 53 DePaul L. Rev. 1557 (2004); Coker v. Georgia, 433 U.S. 584 (1977) (holding that the death penalty is a grossly disproportionate sentence for the crime of rape); Elizabeth Rapaport, Capital Murder and the Domestic Discount: A Study of Capital Murder
} 
For example, the case of Barefoot $v$. Estelle ${ }^{54}$ offers students the opportunity to ask whether future dangerousness should be considered in imposing the death penalty, ${ }^{55}$ and also whether the likelihood of the defendant's future dangerousness has been established by reliable evidence in a particular case. ${ }^{56}$ Through an examination of the justices' sharp disagreements about the reliability of psychiatric predictions generally, and in particular, the testimony of the infamous Dr. Grigson, students are able to gain valuable insights into the role of expert witnesses, particularly psychiatrists and psychologists.

Similarly, the Supreme Court's decision in Atkins v. Virginia ${ }^{57}$ prohibiting the execution of the mentally retarded has opened a new era in death penalty jurisprudence, in which entire classes of persons are excluded from death penalty eligibility due to shared class characteristics. ${ }^{58}$ Discussing the unfinished business of Atkins, the factors and processes that are likely to be used by the lower courts in deciding whether or not a

in the Post-Furman Era, 49 S. M. U. L. Rev. 1507, 1510 (1986) (finding significant gender differences in the imposition of the death penalty) and Elizabeth Rapaport, The Death Penalty and Gender Discrimination, 25 Law \& Society Rev. 367, 368 (1990) (arguing that "[t]he chivalry from which women supposedly benefit [in being sentenced less often to death when circumstances might otherwise warrant] is too costly: In ideological coin it is supposed to be repaid with tacit recognition of the moral inferiority of females and our lack of aptitude for full citizenship.”).

${ }^{54} 463$ U.S. 880 (1983).

${ }^{55}$ See also Jurek v. Texas, 428 U. S. 262 (1976).

${ }^{56} 463$ U.S. at .

${ }^{57} 536$ U.S. 304 (2002).

${ }^{58}$ Roper v. Simmons, 125 Sup. Ct. 1183 (2005) (holding that juveniles who were less than 18 at the time they committed the crime charged cannot be executed). Of course, another significant aspect of both decisions was the extent to which the majority opinions relied on law from other jurisdictions to support its conclusions about the content of "evolving standards of decency" under the Eight Amendment. See e.g., Rex D. Glensy, Which Countries Count? Lawrence v. Texas and the Selection of Foreign Persuasive Authority, 45 Va. J. Int'l L. (2005). 
specific defendant is mentally retarded ${ }^{59}$ can enhance students' understanding of the ranges of retardation and developmental disabilities, as well as the differences between mental retardation and mental illness.

\section{B. Mental Disability and Sex Offenders}

Finally, discussion of specialized sex offender legislation permits students to confront again the purposes of punishment and the elusive nature of the "mad vs. bad" distinction. Sex offender statutes, and the indefinite "civil" commitment which they authorize, ${ }^{60}$ highlight the limitations of the free will model of human behavior on which the Anglo-American criminal law relies. Here again, the gap between what neuroscience and psychological research tells us and the responses of state legislatures and judiciaries to sex offenders is wide indeed. In discussing the involuntary commitment of sex offenders, students are called upon to confront the arbitrary and unclear line between confining people for purposes of punishment and confining them in order that they be "treated" and incapacitated for public protection, in order to round

\footnotetext{
${ }^{59}$ See, e.g., Bill Lockyer and Taylor S. Carey, Capital Punishment and the Mentally Retarded: Implementing Atkins, 15 Stan. L. \& Pol'y Rev 329, 334-40 (2004).

${ }^{60}$ See, e.g., Kansas v. Hendricks, 521 U.S. 346 (1997) (upholding Kansas’ Sexually Violent Predator Act, which permitted the indefinite confinement for "treatment" for those who had served a term of imprisonment who were found to suffer from "a mental abnormality or personality disorder which makes the person likely to engage in predatory acts of sexual violence" against a substantive due process challenge), and Kansas v. Crane, 534 U.S. 407 (2002) (holding that the Kansas Sexually Violent Predator Act was constitutional because it required the state to show that the alleged sexual predator had a substantial volitional impairment).
} 
out their understanding of the purposes of punishment and the limits of the police power.

\section{CONCLUSION}

The criminal law course can be greatly enhanced by using cases involving mentally disabled offenders to illustrate a wide variety of doctrinal principles. Exposing students to the complexities of mental illness and mental retardation makes the course more nuanced and more "real," and provides a useful lens through which to examine the policy choices underlying penal legislation and decisions in individual cases. Far from being an "add-on" or an additional burden, discussing mental disability issues throughout the criminal law course permits students to emerge from the course with a deeper understanding of the fundamental conundrums of the criminal law. 